\title{
Cross-cultural comparison of plant use knowledge in Baitadi and Darchula districts, Nepal Himalaya
}

\author{
Ripu M. Kunwar ${ }^{1,2^{*}}$ (D), Maria Fadiman², Mary Cameron ${ }^{3}$, Rainer W. Bussmann ${ }^{4}$, Khum B. Thapa-Magar ${ }^{5}$,
} Bhagawat Rimal ${ }^{6}$ and Prabhat Sapkota ${ }^{7}$

\begin{abstract}
Background: This study seeks to better understand the human-nature interface and to measure the variability of plant use knowledge among cultures, through inter- and intracultural analyses. We compared plant collection, use, and management of two culturally distinct groups (Baitadi and Darchula) of the Nepal Himalaya. They inhabit different physiographic regions, yet share the same ecological landscape, environmental resources, and livelihood challenges. We hypothesized that the elderly, native, and traditional healers living in remote and rural places possess more diverse and detailed knowledge of plant use and conservation than young, non-native, and non-healers.

Methods: A total of 106 people were contacted for interviews, and 100 (68 men and 32 women) agreed to share ethnobotanical, demographic, and socioeconomic information. They were asked about the three most important plants for their socioeconomic benefit, culture, primary health care, and livelihood.

Results: The knowledge of plant collection, use, and its transfer was strongly associated with the cultural heritage whereas the ecogeographical condition influences the ways in which plants are collected and used. The divergent knowledge of plant collection, use, and transfer between the participants of Baitadi and Darchula was significantly $(p<0.001)$ attributed to the cultural heritage of the area. The low consensus of plant use (FiC $0-0.87 ;$ IASc $0-0.67$ ) between Baitadi and Darchula district could be due to cultural divergence, varied accessibility, physiographic heterogeneity, and biodiversity uniqueness.

Conclusions: Differences in plant use knowledge may help in diversifying the strategies of plant use in accordance with the livelihood, culture, and environment, and therefore, more studies measuring these aspects can further the ecosystem and cultural health of the region.
\end{abstract}

Keywords: Medicinal plants, Use reports, Consensus, Transhumance, Intracultural, Nepal Himalaya

\section{Background}

Human communities that inhabit remote and rugged ecosystems use diverse livelihood strategies such as utilizing different ethnoecological environments $[1,2]$ defined by the availability of plants [3], altitudinal gradient and accessibility [4], culture [5, 6], and adaptation [7]. When there is little arable land, indigenous livelihood strategies include animal husbandry, transhumance,

\footnotetext{
* Correspondence: ripukunwar@gmail.com

${ }^{1}$ Ethnobotanical Society of Nepal, GPO Box 19225, New Road, Kathmandu 44600, Nepal

${ }^{2}$ Department of Geosciences, Florida Atlantic University, Boca Raton, USA Full list of author information is available at the end of the article
}

seasonal crop production, and collection, use, and trade of medicinal plants [8-10]. However, changes in lifestyle as a result of globalization, increasing population, land-use change, and climate warming affect these livelihood strategies. Socio-acculturation of mountain people and plants jeopardizes the human-biodiversity linkage in the region [11]. The collection and use of plants, hailed for socioeconomic gain, cultural heritage, and drug development [12-15], has now been threatened due to local people's changing perceptions and their context-specific socioeconomic and cultural transformations [16-18].

The knowledge and practice associated with the collection and uses of plants vary within any culture, 
because of the abundance and quality of species, geography of the region, origin of the plants, residence of the people, social status, and relationships within the community [9, 19-22]. Cultural factors are sometimes mediated through local classification systems [23], language $[24,25]$, human cognition, cultural history [26, 27], beliefs, religion [28, 29], taboos, social networks, and access to information $[19,30]$. Different subsets of sociocultural factors such as settlement, population, family size, gender, age, ethnicity, education, economy, occupation, and possession also influence knowledge of plant use [3, 7, 31-35]. Studies have demonstrated that ethnobotanical knowledge increases with an individual's age and length of residence [36]. Thus, cultural variables seem more essential in explaining community knowledge of collection and plant use [24] in addition to the sustainability of plant resources. A continuous outmigration foments a decline in the number of healers and indigenous knowledge holders [37-41], resulting in weakened indigenous knowledge and use systems [42].

Here, we compared the knowledge of plant collection and use of two subculturally distinct groups inhabiting different physiographic regions within the same ecological landscape with access to similar environmental resources. Cross-cultural studies were parsimoniously studied before 1998 [43], but nowadays, they are increasingly being analyzed [25, 28, 44-46]. Intercultural comparison has practical applications because we can address both the consensus and variations of plant use knowledge. In this paper, we carried out a cross-cultural study focusing on different human groups and how their demographic (gender, age), socioeconomic (ethnicity, education, occupation, land and livestock ownership, and food availability), and cultural (length of residence, settlement, language, household size, and livelihood) variables influence the knowledge of plant use. We hypothesized that the elderly, native, and traditional healers living in remote and rural physiographic condition possess more diverse and detailed knowledge of plant use and conservation than young, non-native, and non-healers.

\section{Methods}

\section{Study area}

The Kailash Sacred Landscape (KSL) is a trans-boundary landscape comprised of parts of the southwestern Tibetan Autonomous Region of China and adjacent parts of northern India and northwestern Nepal [47]. At its heart, high upon the Tibetan Plateau lie Mt. Kailash (6638 masl) and two adjacent lakes (Mansarowar), considered a sacred pilgrimage site by over a billion people practicing five religions [11]. The pilgrimage routes to Mt. Kailash and Mansarowar via Urai Pass (Bajhang, Nepal) and Lipulekh (Darchula, Nepal) augment the cultural history of the region [48-54]. The KSL-Nepal occupies $42 \%$ of the total
KSL, which covers four mountain districts (Darchula, Humla, Baitadi, and Bajhang) in the far-western part of the country. This is one of the most underdeveloped regions of Nepal and faces numerous conservation and development challenges because of the harsh climate, poor accessibility, marginality, and high level of poverty $[47,55]$. These cultural and developmental premises are intertwined with historical accounts. Before the Anglo-Nepalese War (Gurkha War) of 1814-1816, the entirety of Kumaon Garhwal to Bairath (Baitadi), Doti was designated as the Katyuri Kingdom under Nepal administration [56], and the corpus of feudal rites was considered a unifying aspect of culture [57]. There are a number of commemorative pillars erected in about 1200 AD in Dehimandu, Baitadi, and adjoining areas memorializing the victorious warriors of the region [58]. The long history of contact of a community with nature infers a tradition and culture that integrate a high number of indigenous medicinal plants for local livelihood [26]. Only about $15-25 \%$ of the KSL geographical area is cultivable [11,59-62], leading to prolonged poverty, which contributes to environmental challenges and calls for sustainable development of the region $[15,63]$.

Baitadi and Darchula, the study districts $\left(29^{\circ} 22^{\prime} \mathrm{N}\right.$ to $30^{\circ} 15^{\prime} \mathrm{N} / 80^{\circ} 15^{\prime} \mathrm{E}$ to $81^{\circ} 45^{\prime} \mathrm{E}$ ) located at the westernmost end of the country, represent far-western Nepal bordering India and China (Fig. 1). The study districts Baitadi and Darchula respectively represent hill and mountain ecosystems. Situated in the southern Himalayan foothills, the hill region (Pahad in Nepali) mostly between 700 and $3000 \mathrm{~m}$ above sea level (masl) is highly populated, and agriculture is the main form of livelihood [64]. The mountains are regarded as collection grounds for medicinal plants, summer grazing lands, and sacred sites for rituals $[65,66]$. Traditional mountain agro-pastoral systems predominate in Darchula and integrate with transhumance, animal husbandry, and medicinal plant collection and trade. These livelihood strategies are adapted for subsistence within the steep terrain and variable climatic conditions. Both study districts, extending up to the southern parts of the KSL, are considered important for growing maize, barley, buckwheat, amaranth, potatoes $[67,68]$, and relict hemp culture [69].

\section{Ethnographic setting}

There are more than 30 ethnic and 10 minority groups in the study area including the indigenous groups Byanshi and Santhal in Darchula and Kusunda, Dom and Dhanuk in Baitadi [70]. Chhetri is the study area's dominant ethnic group (about 60\%) followed by Brahmin (about 20\%), Dalit (Lohar/Kami, Sarki, Dhanuk 10\%), and others (10\%). Chhetri and Brahmin are relatively 


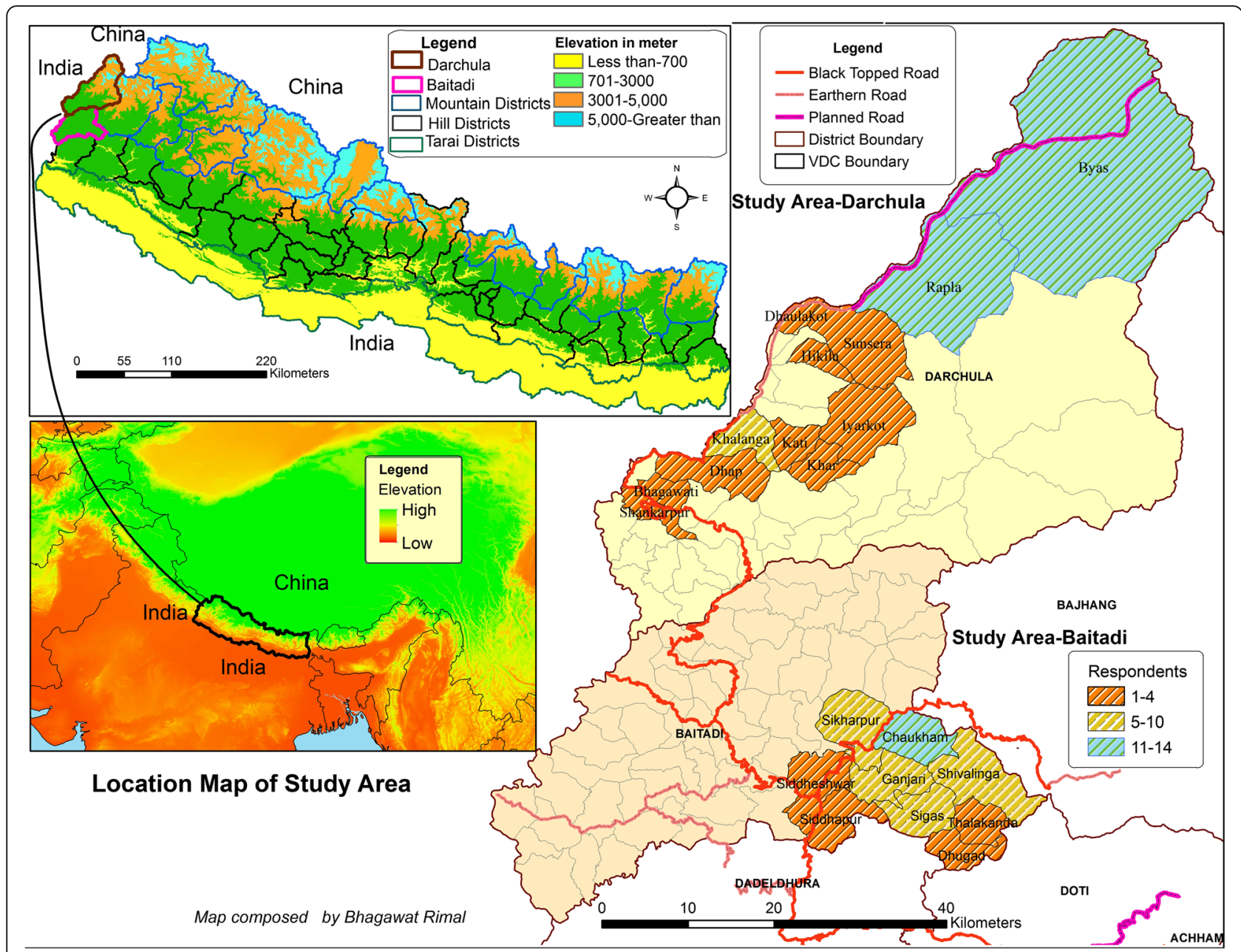

Fig. 1 Map showing the location and physiography of the study area and village-wise frequency of respondents

privileged groups with the highest well-being index [71]. Even though the Dalit are receiving reserved access and opportunities provided by the Nepal Government, they are still disadvantaged due to the sociocultural and class system [55, 72]. The sample community of Baitadi District was composed of sedentary farmers and villagers including the hill castes Chhetri, Brahmin, and Dalit. Brahmin, Chhetri, and Dalit predominate in Baitadi District. Agriculture, wage labor, medicinal plant collection and trade, and traditional healing are the major occupations in Baitadi [35, 73-75]; however, the former contributes the most $[10,76-79]$. Baitadi District is renowned for socioculturally designated sacred peaks [80]. Sacred forests are part of the cultural heritage that represent important spiritual sites [81], and local people believe that their livelihood and cultural existence are greatly dependent on the blessings of their deities [65]. The legacy of sacredness, recently demarcated as the Kailash Sacred Landscape, has been shown to have a major effect on culture, conservation, ecology, and environment due to the associated special precautions and restrictions on use [82]. As a result of limited human activity due to sociocultural taboos and prohibitions, sacred places frequently possess old-growth vegetation and many ecologically and socioculturally valuable plant species $[83,84]$.

The Byanshi is a Tibeto-Burman minority group with a population of about 4000 in the country. About 500 live in Chyanrung and Byansh villages and about 500 in Rapla, Shitola, and Khalanga villages [70]. They are part of a group of people living throughout the Kumaon hills [15], as well as in Darchula (study district), Humla, and Bajhang districts of Nepal [85]. They are semi-nomadic [86], living 6 months in Byansh village ( $>3000$ masl) in the summer and then descending to the lowlands (Khalanga) for the rest of the year [8]. The Byansh village is covered by snow in winter. They represent the cultural practices and belief systems of the Nepal, farwest, and they speak the Byanshi/Rang language [85], claim to be both Hindu and pre-Buddhist and are well known for their hospitality. Byanshi houses are decorated 
with fine wood-carved and reddish-brown-painted windows and doors. Like other Buddhists in Nepal, they use Abies poles for mounting prayer flags in the yard. Abies pindrow Royle (Himisin) is a very good resource as prayer flag, fuelwood, furniture, butter churners, medicine, and agricultural implements in mountain communities. Other temperate-alpine medicinal plant species Angelica archangelica L. (Gannanu), Dactylorhiza hatagirea (D.Don) Soo (Hathajadi), Neopicrorhiza scrophulariflora (Pennell) Hong (Katuko), Ophiocordyceps sinensis (Berk.) G.H.Sung (Yartsagumba), etc. are used and conserved in Darchula District for a long period [87].

The average landholding of a Byanshi family in Darchula District is small and of poor quality, feeding a family only 3 to 4 months in a year [88]. Famines occur often in the district $[47,89]$ aggravated by limited cultivable land. Collection of hay (grasses) and edible and medicinal plants is a common strategy to offset these hungry periods. In addition, a cash crop, radish is sliced, dried, and taken to the northern border Taklakot and into Tibet to barter for salt. Some high-value medicinal plants are bartered to the lowlands and to India in exchange for food and grains [52]. Widespread collection and bartered species are Yartsagumba (O. sinensis), Jimbu (Allium hypsistum Stearn), and Satuwa (Paris polyphylla Sm.). This transboundary trade and transhumance are important livelihood strategies $[52,90]$.

Forest resources and alpine pastures complement the mountain agricultural system in both study districts, meeting fuel, fodder, timber, and medicinal needs. Fuelwood is commonly used for heating and cooking. Agriculture, livestock, woolen products, and the medicinal plant trade are four major livelihoods maintaining household economies. Because of the remote location, reliance on traditional medicine is associated with wild medicinal plants and on the harmonious existence of spirit and matter. Many traditional healers worship and pray to plants before collecting them, acknowledging the spiritual powers of the vegetation [91, 92]. They believe that plants become more medicinal when processed spiritually and materially $[65,66]$. Thus, trade, paired with pastoralism and transhumance in this constrained environment, is a survival strategy $[8,92-94]$. The strategic modes of pasture resource utilization are rotational grazing based on a system of transhumance and medicinal plant harvesting $[95,96]$. However, the traditional trade and transhumance were disrupted when the trade routes were closed in 1962 because of the Sino-Indian border conflict $[97,98]$. This activated contemporary sociocultural and economic transformation, as certain kinds of traditional knowledge began to decline and socio-acculturation and outmigration led people to pursue different economic opportunities to meet new survival challenges $[37,40]$. Thus, the traditional subsistence economy in the far-western Nepal Himalaya has experienced a substantial change in recent decades [11, 29, 35, 99] while certain kinds of traditional knowledge in the research area began to decline in recent decades, including that around human-plant relationships.

\section{Data collection}

Informed consent forms were obtained from all oral interview participants written in accordance with the FAU IRB and Nepal research protocols. Inventory-based interviews [100] were carried out with the help of a local assistant and a research associate in each district. Participants were selected based on the dominant groups in the district, elderly people, and occupational affiliations. Only the traditional healers, plant collectors and traders, and elderly people of ages 40-102 were consulted for interviews. Once a traditional healer or a plant collector/trader was identified, snowball sampling was applied to locate and identify peer respondents. The list of traditional healers and plant collectors was referenced from village secretaries, tea vendors, and earlier studies [75, 101].

A total of 106 people were contacted for interviews, and 100 (68 men and 32 women) agreed to share ethnobotanical, demographic, and socioeconomic information. A two-page semi-structured questionnaire was developed in Nepali script prior to the start of fieldwork and administered for interviews. The interviews were carried out during three field visits, the duration of each trip lasting about a month between February and September 2017. A total of 100 participants including 58 from Chhetri, 14 from Brahmin, 24 from Byanshi, and 4 from Dalit caste group were interviewed. There were 57 participants including 47 Chhetri, 6 Brahmin, and 4 Dalit from 9 villages of Baitadi District and 43 participants including 11 Chhetri, 8 Brahmin, and 24 Byanshi from 12 villages from Darchula district. Informal discussions were held during the evenings while staying with local communities, and sometimes with tea vendors. Tea shops are excellent arenas for observing interactions between communities and discussion of open-ended questions [102].

In the interview, the participants were asked to list the three most important plants for each category, e.g., socioeconomic benefit, culture, primary health care, and livelihood. Demographic information was collected for each participant including socioeconomic status, age, occupation, education, family size, livestock, land ownership, where they migrated from, languages they speak, length of residence, distance of home from district center, nearest health post, and forest. Interviews were supplemented with other investigative techniques, such as participant observation, walk-in-the-woods interviews, and informal meetings [103]. Interviews were conducted individually whenever possible to avoid any direct 
influences from third parties. The sampling effort was tested by a Jackknife first-order richness estimator 100 permutation species-use curve performed in R. Species-use curve was drawn from the cumulative number of species mentioned as being used versus the number of informants interviewed [104]. While participating in the guided tours, voucher specimens of the species that could not be identified in the field were collected by participants and field assistants and processed and deposited at the Plant Laboratory and Herbarium (KATH), Lalitpur, Nepal, for future reference. Earlier studies carried in and around the study area $[60,75,98,100]$ were used as a taxonomic reference of general species. Plant taxon was verified by using The Plant List (Retrieved from www.theplantlist.org).

\section{Data analysis}

Matching information (use reports) from at least three respondents was considered a common response for quantitative analysis [33]. To determine the influence of socioeconomic factors, we used three different indicators of knowledge: (1) use reports, representing the sum of all uses reported by an informant for all species known by that person; (2) useful species, representing the sum of all useful species an informant knew; and (3) use value. Emic use types were later grouped into 19 etic categories for further analyses following Cook [105]. To identify the proportion of culturally important species in each study district, the Index of Agreement on Species (IAS) was calculated following Trotter and Logan [106]:

$$
(\mathrm{ns}-\mathrm{nu}) /(\mathrm{ns}-\mathrm{l}) \text {, }
$$

whereby ns is the number of use reports of a given species mentioned by all the participants, and nu is the number of use types attributed to that species. IAS was corrected to Index of Agreement on Species consensus (IASc) for the number of participants who knew a use for the species through the formula:

$$
\mathrm{IASc}=\mathrm{IAS} \times(\mathrm{Pu} / \mathrm{Pt})
$$

where $\mathrm{Pu}$ represents the number of participants who reported a use, and Pt equals the total number of participants interviewed about the species [107]. IASc values vary between 0 and 1 , with 0 representing no agreement and 1 total agreement. In this paper, we determined the proportion of plant species with an IASc value $>0.5$; this value was chosen as an arbitrary cutoff point for culturally important species following Vandebroek [107].

The frequency of citation of a specific use, that is, the number of individual use reports (nur) for a type of use category, serves to establish the consensus across the respondents [108]. The cultural consensus on a particular use category can help inform efficacy of a plant to that particular use category [106, 109]. The efficacy of plants can be perceived by determining the Fic values. The informant consensus factor $(\mathrm{FiC})$ was calculated as:

$$
\text { nur-nspp.used/nur-1 }
$$

where nur shows the number of use reports while nspp shows the number of species used [106]. After analyzing the $\mathrm{FiC}$ values of both districts, a comparison was made to sort out the consensus of uses across the two districts. The two main measures of "plant knowledge" consisted of (1) the cumulative number of participants who reported a use for each plant species at the group (cultural) level and (2) the number of plant species used at the level of individual participant. Other measures used to correlate plant knowledge with consensus included the unique use reports (UUR) by a participant.

\section{Statistical analysis}

We grouped the socioeconomic and demographic data into nominal/categorical variable: (1) gender, (2) education, (3) occupation, (4) livelihood type, (5) access to opportunity, (6) food availability, (7) languages spoken and continuous variable: (1) age, (2) household size, (3) livestock size, (4) land size, (5) length of residence, (6) years of healing practice, (7) distance from home to forest, and (8) distance from home to health post. Cross-cultural analysis was made by (1) gender: male and female, (2) education: literate and non-literate, (3) occupation: traditional healers and non-healers, (4) livelihood type: suburban, hill, and sedentary (Baitadi District); rural, mountain and semi-nomadic (Darchula District), (5) food availability: $<6$ and $>6$ months, (6) language spoken: two languages spoken and more, and (7) access to opportunity: privileged group (Chhetri and Brahmin) and under-privileged (Byanshi and Dalit).

Statistical models were used to explore how sociocultural variables interact among themselves and with the knowledge of plant collection, use, and management intensity. We considered $p$ values $<0.05$ as statistically significant [110]. For count variables, a generalized linear regression model with Poisson logit (link) was used to see the effect of the settlement, length of residence, size of household, livestock and land, and age and experience of participants against plant uses. For categorical variables, emmeans (least square regression of means at logical scale) generalized linear model was used [111]. All the analyses were performed in R studio in R 3.4.1 ( $R$ Development Core Team 2017).

\section{Results}

\section{Useful species and cultural consensus}

A total of 1434 use reports from 122 useful plant species were recorded from 100 participants. Each species was 
reported for 1-10 use types and 1-63 use reports. The participants from Baitadi District recorded 917 use reports (16.08 person $^{-1}$ use reports) whereas that of Darchula District was $517\left(12\right.$ person $\left.^{-1}\right)$ (Additional file 1). The use reports were assigned to 89 emic use types later categorized into 19 etic categories for further analyses (Table 1). Of 122 useful plant species, 102 were found useful in Baitadi and 92 in Darchula, with 72 common. The species-use curve approached an asymptote as the number of interviews increased in Baitadi District (57 participants) indicating that there will not be further additions of useful species. However, the curve was not completely leveled-off in Darchula District (43 participants) indicating that further sampling of respondents would yield some new useful species in Darchula District (Fig. 2).

Of the 19 categories we grouped, 16 categories were found significant for both districts. The categories with less than three use reports were not considered for further analysis (Fig. 3, left). The recorded FiC values for 19 categories were ranged from 0 to 0.87 in both of the districts revealed that the use reports are species-specific and less shared among the participants and district groups. In comparison, highest $\mathrm{FiC}$ value was reported for sociocultural and livelihood use (wood, fuel, fodder) (FiC 0.87) in Baitadi District in contrast to the highest FiC value (0.83) recorded for medicinal use treatment of gallstone and endocrine aliments in Darchula District. The second highest FiC 0.85 and 0.81 respectively for Baitadi and Darchula districts were recorded for ritual purpose use (Table 1).

We considered IASc $>0.5$ as a cutoff value for identifying the highly consented species. Results showed that there are eight species with IASc value $>0.5$ (Table 2). The comparison of informant agreement values between the Baitadi and Darchula districts was significantly different $(p<0.001)$. In order to investigate the relationship between plant knowledge and consensus at the group (cultural) level, plant species were ranked according to their IASc

Table 1 Emic and etic use categories and informant consensus factor (FiC)

\begin{tabular}{|c|c|c|c|c|c|c|c|c|}
\hline \multirow{2}{*}{$\begin{array}{l}\text { Etic category } \\
\text { (abbreviation) }\end{array}$} & \multirow[t]{2}{*}{ Emic use type } & \multicolumn{3}{|l|}{ Baitadi } & \multicolumn{3}{|c|}{ Darchula } & \multirow[t]{2}{*}{ Av. } \\
\hline & & $\begin{array}{l}\text { Use } \\
\text { reports }\end{array}$ & $\begin{array}{l}\text { Useful } \\
\text { species }\end{array}$ & $\mathrm{FiC}$ & $\begin{array}{l}\text { Use } \\
\text { reports }\end{array}$ & $\begin{array}{l}\text { Useful } \\
\text { species }\end{array}$ & $\mathrm{FiC}$ & \\
\hline Ritual (Rit) & Ritual, religious, evil spirits, luck & 120 & 18 & 0.857 & 85 & 20 & 0.773 & 0.815 \\
\hline $\begin{array}{l}\text { Digestive metabolism } \\
\text { (Dig) }\end{array}$ & $\begin{array}{l}\text { Diarrhea, dysentery, stomachache, nausea, } \\
\text { anthelmintic, appendicitis, gastric, indigestion }\end{array}$ & 102 & 23 & 0.782 & 137 & 35 & 0.75 & 0.766 \\
\hline Infection (Inf) & TB, fever, typhoid, tetanus, leprosy, polio & 47 & 14 & 0.717 & 78 & 19 & 0.766 & 0.741 \\
\hline Social materials (Soc) & $\begin{array}{l}\text { Wood, fuel, fodder, forage, rope, bedding, } \\
\text { agricultural implements }\end{array}$ & 272 & 36 & 0.870 & 28 & 16 & 0.444 & 0.657 \\
\hline Pain inflammation (Pai) & $\begin{array}{l}\text { Cuts, wounds, burn, injury, analgesic, } \\
\text { toothache, headache }\end{array}$ & 53 & 23 & 0.576 & 45 & 16 & 0.659 & 0.618 \\
\hline Respiratory (Res) & Pneumonia, cold, cough, larynx-sound & 58 & 23 & 0.614 & 22 & 9 & 0.619 & 0.616 \\
\hline Livestock (Liv) & Livestock health, veterinary & 19 & 15 & 0.222 & & & & 0.111 \\
\hline Musculoskeletal (Mus) & $\begin{array}{l}\text { Fracture, sprain, joint pain, backache, } \\
\text { bath (rheumatism) }\end{array}$ & 36 & 16 & 0.571 & 24 & 12 & 0.521 & 0.546 \\
\hline Anti-poisoning (Poi) & $\begin{array}{l}\text { Snake bite, antidoting, scorpion sting, } \\
\text { piscicidal, antileech, insecticidal }\end{array}$ & 21 & 10 & 0.55 & 11 & 6 & 0.5 & 0.525 \\
\hline Food (Foo) & Vegetable, edible, spices & 43 & 20 & 0.547 & 10 & 6 & 0.444 & 0.496 \\
\hline Immune (Imm) & $\begin{array}{l}\text { Immune, anticancer, nutrition, appetite, } \\
\text { growth, tonic }\end{array}$ & 4 & 3 & 0.333 & 18 & 7 & 0.649 & 0.324 \\
\hline Endocrine (End) & Gall bladder, gall stone, diabetes & & & & 13 & 3 & 0.833 & 0.416 \\
\hline Genito-urinary (Gen) & Urine infection, hydrocele, piles & 9 & 3 & 0.75 & 3 & 3 & 0 & 0.375 \\
\hline Circulatory blood (Cir) & Blood pressure, heart disease, jaundice & 15 & 10 & 0.357 & 16 & 12 & 0.266 & 0.311 \\
\hline $\begin{array}{l}\text { Household economy } \\
\text { (Eco) }\end{array}$ & Dye, oil, resin & 13 & 6 & 0.583 & & & & 0.291 \\
\hline Reproductive (Rep) & $\begin{array}{l}\text { Lactation, fertility, conceive, abortion, } \\
\text { dudhelo (mammary gland complication) }\end{array}$ & 7 & 4 & 0.5 & 4 & 4 & 0 & 0.25 \\
\hline Skin (Ski) & $\begin{array}{l}\text { Acne, scabies, skin swell, hair fall, makada, } \\
\text { pilo, pitka (skin rashes) }\end{array}$ & 35 & 18 & 0.5 & 6 & 6 & 0 & 0.25 \\
\hline Nervous (Ner) & $\begin{array}{l}\text { Paralysis, memory longevity, dizziness, } \\
\text { antidepressant, chito (epilepsy) }\end{array}$ & 12 & 11 & 0.090 & 9 & 9 & 0 & 0.045 \\
\hline Sensory (Sen) & Eye, ear & 3 & 3 & 0 & 0 & 0 & 0 & 0 \\
\hline
\end{tabular}




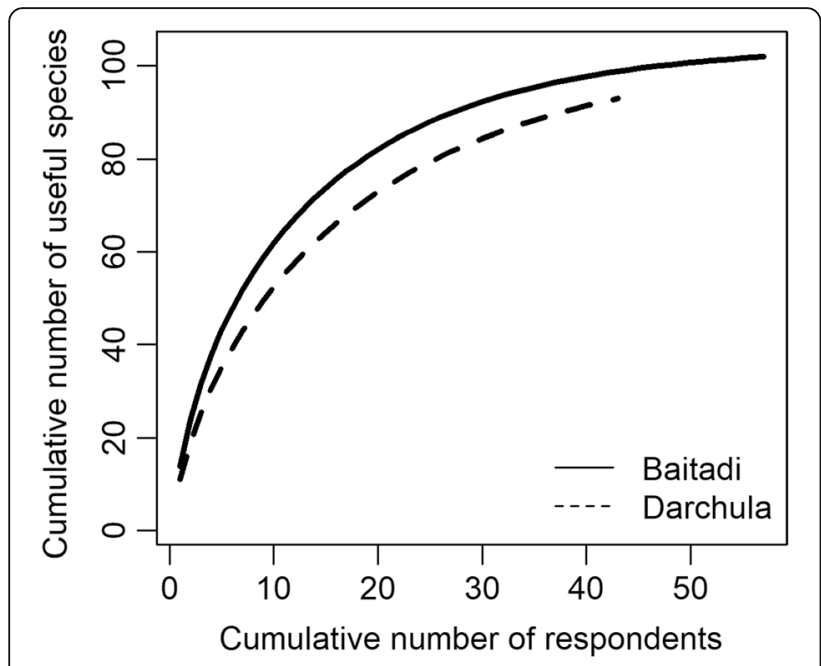

Fig. 2 Species-use curve showing the records of the number of useful species against the number of respondents leveled off after 50th participant

value. In Baitadi, an IASc value $>0.5$ was obtained for five species: Prunus cerasoides, A. pindrow, Chrysopogon aciculatus (Retz.) Trin., Bergenia ciliata (Haw.) Sternb., and Quercus lanata Sm. whereas only three species: Angelica archangelica, N. scrophulariflora, and P. polyphylla were recorded as the highest IASc value $>0.5$ species in Darchula (Table 2, Fig. 3). Species with $<0.5$ IASc are given in Additional file 1.

Analysis of use value of plants in two different cultures revealed that three species $P$. polyphylla, $N$. scrophulariflora, and $A$. archangelica are medicinal in uses and emerged in quadrant " $D$ " with their high IASC value (0.55-0.67) in Darchula District (Fig. 3, right). Five species appeared in quadrant "B" (A. pindrow, B. ciliata, $C$. aciculatus, $P$. cerasoides, and $Q$. lanata) with high IASc value ( $>0.5$ ) were important in Baitadi District. Of the five $>0.5$ IASc species in Baitadi, only one species $B$. ciliata was used as medicinal, and the rest four were used for sociocultural purposes. A pindrow was valued as a timber/wood species, Q. lanata as a fire-wood and fodder, $C$. aciculatus as forage for livestock feeding, and $P$. cerasoides for ritual ceremonies. The species appeared in quadrant " $\mathrm{A}$ " were highly consented in both districts whereas those that appeared in quadrant "C" were insignificant in uses and consensus. None of the species was highly consented in both district indicated that the use value of plant species was specific to the district groups and culturally divergent.

\section{Intracultural knowledge}

A total of 15 sociocultural factors were tested against the three types of plant use reports: medicinal use reports-MUR, other use reports-OUR, and unique use reports-UUR (Additional file 2). Of the eight continuous variables, four-length of residence, possession of livestock and land, and the distance required to access health post-were found significant $(p<0.001-0.03)$ for both MUR and OUR (Table 3, Fig. 4). Other factors such as distance required for forest access, length of healing practice, and household size of the participants were insignificant for MUR; however, OUR was partially influenced. The unique use report (UUR) was indifferent to continuous variables at all. UUR was also insignificantly different at all categorical variables except the opportunity access and education of the participants $(p=0.045$ and 0.043 , respectively) (Tables 3 and 4).
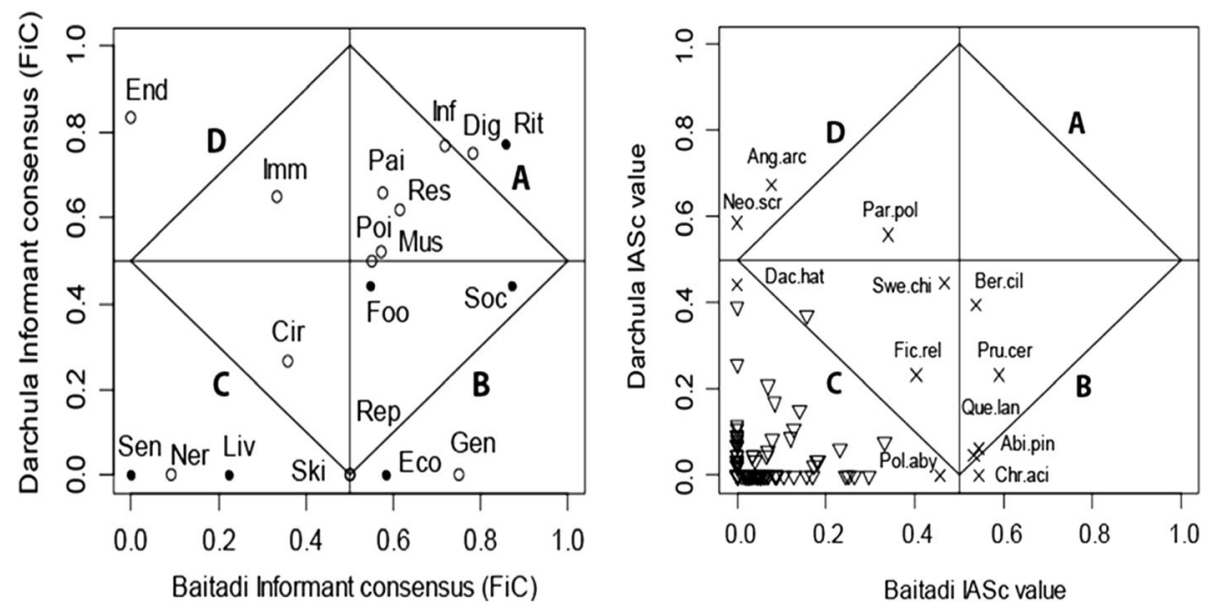

Fig. 3 Cultural consensus matrix of two groups (Baitadi and Darchula participants). Right—species: Abi.pin = A. pindrow, Ang.arc = A. archangelica, Ber.cil $=$ B. . ciliata, Chr.aci $=$ C. aciculatus, Fic.rel $=$ F. religiosa, Neo.scr $=$ N. scrophulariflora, Par.pol $=$ P. polyphylla, Pol.aby $=$ P. abyssinica, Pru.cer $=$ P. cerasoides, Que.lan = Q. lanata, and Swe.chi $=$ S. chirayita. Left-use category: Cir = circulatory, Dig = digestive, Eco = economic, End = endocrine; Foo = food, Gen = genito-urinary, Imm = immune, Inf = infections, Liv = livestock, Mus = musculoskeleton, Ner = nervous, Pai = pain, Poi = antipoisoning, Rep $=$ reproductive, Res $=$ respiratory, Rit $=$ ritual, Ski $=$ skin-cutaneous, Sen $=$ sensory, and Soc $=$ social 
Table 2 Plant species with high IASc scores $>0.5$

\begin{tabular}{|c|c|c|c|c|c|c|c|c|c|}
\hline \multirow[t]{2}{*}{ Scientific name (abbreviation) } & \multirow[t]{2}{*}{ Family } & \multicolumn{4}{|l|}{ Baitadi } & \multicolumn{4}{|l|}{ Darchula } \\
\hline & & Use types \# & Use reports & Participants (n) & IASC & Use types \# & Use reports & Participants (n) & IASC \\
\hline $\begin{array}{l}\text { Abies pindrow (Royle ex D.Don) } \\
\text { Royle }\end{array}$ & Pinaceae & 1 & 31 & 31 & $0.543^{*}$ & 2 & 4 & 4 & 0.062 \\
\hline Angelica archangelica L. & Apiaceae & 4 & 9 & 7 & 0.076 & 2 & 30 & 30 & $0.673^{*}$ \\
\hline Bergenia ciliata (Haw.) Sternb. & Saxifragaceae & 7 & 42 & 36 & $0.539^{*}$ & 3 & 20 & 19 & 0.395 \\
\hline $\begin{array}{l}\text { Chrysopogon aciculatus (Retz.) } \\
\text { Trin }\end{array}$ & Poaceae & 1 & 31 & 31 & $0.543^{*}$ & 1 & 1 & 1 & 0 \\
\hline $\begin{array}{l}\text { Neopicrorhiza scrophulariflora } \\
\text { (Pennell) D.Y. Hong. }\end{array}$ & Plantaginaceae & 1 & 1 & 1 & 0 & 4 & 31 & 28 & $0.586^{*}$ \\
\hline Paris polyphylla Sm. & Melanthiaceae & 5 & 27 & 23 & 0.341 & 4 & 28 & 27 & $0.558^{*}$ \\
\hline $\begin{array}{l}\text { Prunus cerasoides Buch.-Ham. } \\
\text { ex D.Don }\end{array}$ & Rosaceae & 4 & 47 & 36 & $0.590^{*}$ & 1 & 10 & 10 & 0.232 \\
\hline Quercus lanata Sm. & Fagaceae & 7 & 58 & 34 & $0.533^{*}$ & 2 & 4 & 3 & 0.046 \\
\hline
\end{tabular}

$n=$ respondents in district, total respondents $(N)=100$

*Significant

The participants living in the study area for generations possessed the highest knowledge of plant use, which was significantly different $(p<0.001)$ from participants who moved there more recently. Higher plant use knowledge was also associated with the participants who had a larger number of livestock $(p<0.001)$ and greater land size $(p<0.001)$ and family member $(p=0.001)$; however, the latter was insignificant $(p=0.148)$ to OUR. The settlement: distance from home to a health post $(p<0.001)$ and home to forest $(p=0.002)$ was positively associated to MUR; however, the OUR knowledge was insignificant to the distance of home to the forest. Unlike other studies, age of the participants did not show any statistically significant variation $(p=0.55)$ on means of the knowledge of plant use at all (Table 3). Contrarily, the healing experience of the participants was negatively associated with MUR $(p=0.028)$. Mixed result was obtained when the participants were categorized into healers and non-healers by their occupation and assessed their knowledge of MUR $(p=0.17)$ and OUR $(p<0.001)$. Though healers were more knowledgeable on MUR (7.79), it was statistically insignificant $(p=0.17)$. They also provided less knowledge about OUR (5.83) and UUR (1.99) than the non-healer respondents.

In the study area, the variation of plant use knowledge was closely related to the categorical variables: livelihood, access to opportunity, gender, occupation, and language spoken by the participants, among which livelihood was significant $(p<0.001)$ for both MUR and OUR. The latter four were significant for OUR and UUR. Even though participants responded differently about the plant recognition, identification, collection, and uses [112], this finding was beyond the scope of this present study, and we analyzed only the use responses of the participants. We partially rejected our null hypothesis and found that a significant difference $(<0.001)$ on plant use knowledge was between the participants with agribusiness and agro-pastoral livelihood and hill/suburban and remote/rural setting.

Table 3 Generalized linear model (Poisson's) regression coefficients of continuous variables against plant use reports

\begin{tabular}{lllll}
\hline SN & Explanatory variables (continuous) & Medicinal (MUR) & Others (OUR) & Unique (UUR) \\
\hline 1 & Length of residence (year) & $<0.001^{* * *}$ & $0.030^{*}$ & 0.077 \\
2 & Livestock owned (number) & $<0.001^{* * *}$ & $<0.001^{* * *}$ & 0.795 \\
3 & Land owned (number) & $<0.001^{* * *}$ & $0.013^{*}$ & 0.698 \\
4 & $<0.001^{* * *}$ & $0.001^{* * *}$ & 0.145 \\
5 & Home-health post-distance (hour) & $0.002^{* *}$ & 0.356 & 0.148 \\
6 & Home-forest distance (hour) & $0.001^{* *}$ & 0.060 & 0.141 \\
7 & Household size (number) & $0.028^{*}$ & 0.115 & 0.854 \\
\hline$>0.05$ non & Healing practice (year) & 0.556 & 0.651 \\
\hline
\end{tabular}

$>0.05$ non-significant $(\mathrm{Ns})$

***Highly significant

**Moderately significant

*Low significant 


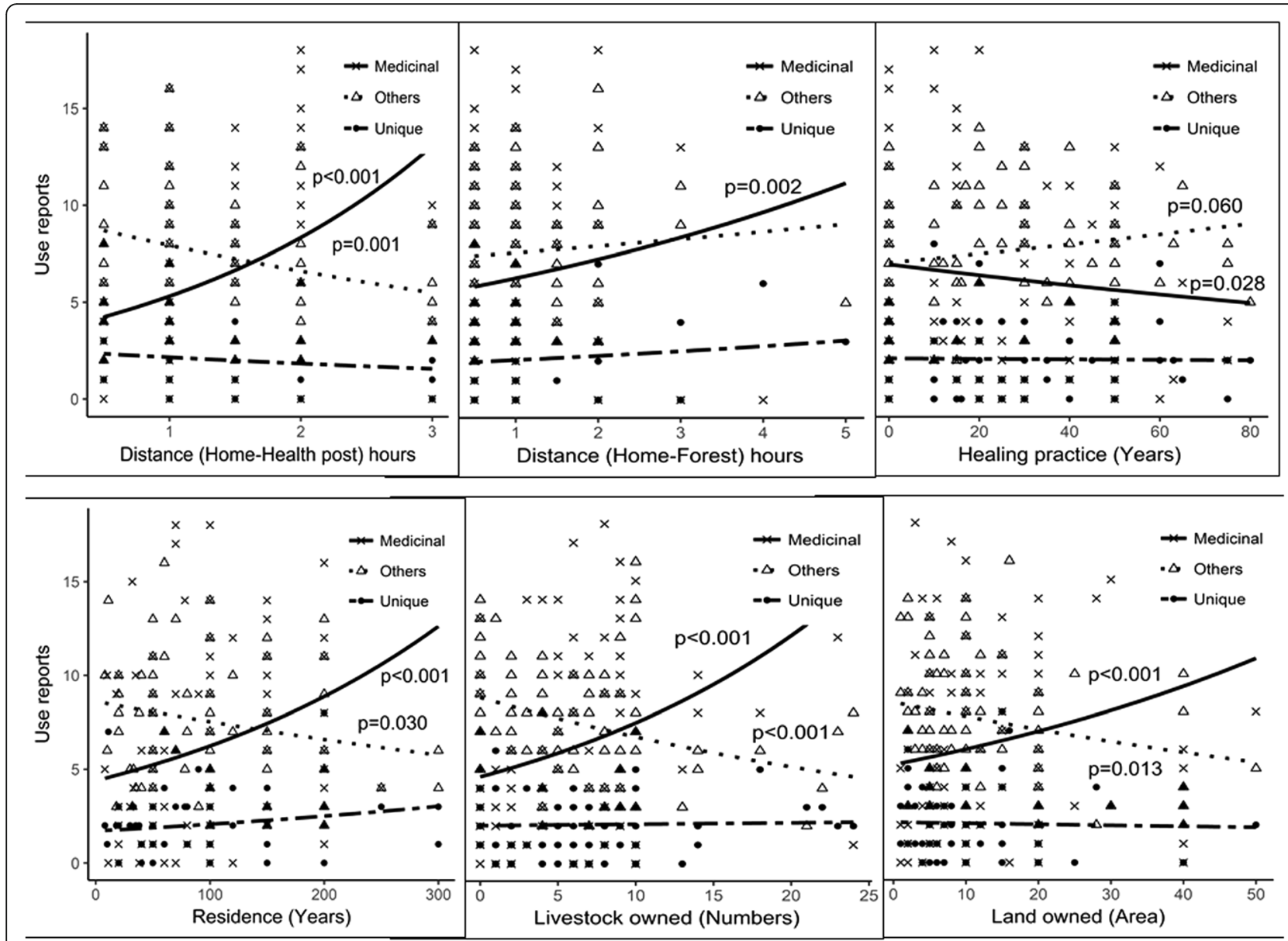

Fig. 4 Generalized linear model regression of plant use knowledge of participants along the gradients of sociocultural asset, length of residence, and the time required to access resources. Column represents number of use reports cited by participants

\section{Discussion}

\section{Useful plants and their use values}

The account of 122 useful plant species was about 50\% of the total 255 plant species recorded from the districts. The record of higher number of medicinal plants and edible fruits from herbs and trees respectively was in line with the findings of Toledo et al. [19]. The extensive usage of plants for livelihood and health care indicates that this is clearly an important part of the culture. Poaceae was a richly represented plant family with eight useful plant species followed by Moraceae with seven, Apiaceae with six, and Asteraceae and Fabaceae with five each. Our record of higher number of useful plant species from Poaceae, Asteraceae, and Fabaceae, the most species-rich plant families in the world, was supported by the hypothesis of Moerman [113]; families with abundant species emerges with an abundance of useful species. Asteraceae and Poaceae are the richest plant families in Darchula [50, 114]. Records of higher numbers of useful plant species from the plant families Asteraceae, Fabaceae, and Rosaceae were already manifested in and around KSL, Nepal [15, 49, 74, 77, 99, $115,116]$. Family-wise, the IASc value also revealed that the families Poaceae and Fagaceae were highly consented as useful (IASc 0.79 and 0.59 , respectively) followed by Rosaceae and Pinaceae 0.54 each.

\section{Intercultural analysis}

The species with high consensus $(>0.5)$ were greatly varied at use types and district level. Out of 122 useful botanical taxa documented in this study, only three species $A$. archangelica, $P$. polyphylla, and $N$. scrophulariflora received the highest consensus (IASc $>0.5$ ) among the participants of Darchula. All three species were used as medicine. The use of $N$. scrophulariflora against fever and headache was folkloric with higher IASc in KSL, Nepal, supported by the earlier findings $[15,115,116]$. $P$. polyphylla was considered as a common antidoting plant and $A$. angelica as effective herbal for indigestion in traditional medicine. Species A. pindrow, B. ciliata, $C$. aciculatus, $P$. cerasoides, and $Q$. lanata received the highest IASc (>0.5) among the participants of Baitadi. 
Table 4 Analysis of deviance of three types of use reports (MUR, OUR, UUR) in response to livelihood, ethnicity, gender, occupation, education, language spoken, and availability of food in generalized linear model fit with Poisson coefficients

\begin{tabular}{|c|c|c|c|c|c|c|c|}
\hline \multirow{2}{*}{$\begin{array}{l}\text { Explanatory variables } \\
\text { (categorical) }\end{array}$} & \multirow[t]{2}{*}{ Factors } & \multicolumn{2}{|l|}{ MUR } & \multicolumn{2}{|l|}{$\underline{\text { OUR }}$} & \multicolumn{2}{|l|}{ UUR } \\
\hline & & Mean & $p$ & Mean & $p$ & Mean & $p$ \\
\hline \multirow[t]{2}{*}{ Livelihood } & Baitadi/sedentary (suburban, hill) (57) & 6.75 & $<0.001^{* * *}$ & 8.92 & $<0.001^{* * *}$ & 2.06 & 0.99 \\
\hline & Darchula/semi-nomadic (rural, mountain) (43) & 8.69 & & 2.88 & & 2.04 & \\
\hline \multirow[t]{2}{*}{ Access to opportunity } & Privileged (Brahmin, Chhetri) (72) & 7.40 & 0.27 & 7.38 & $<0.001^{* * *}$ & 2.24 & $0.045^{*}$ \\
\hline & Underprivileged (Byanshi, Dalit) (28) & 8.07 & & 3.60 & & 1.60 & \\
\hline \multirow[t]{2}{*}{ Gender } & Male (68) & 7.59 & 0.99 & 6.72 & $0.023^{*}$ & 2.26 & 0.49 \\
\hline & Female (32) & 7.58 & & 5.49 & & 2.36 & \\
\hline \multirow[t]{2}{*}{ Occupation } & Healers (77) & 7.79 & 0.17 & 5.83 & $<0.001^{* * *}$ & 1.99 & 0.79 \\
\hline & Non-healer (23) & 6.91 & & 7.99 & & 2.02 & \\
\hline \multirow[t]{2}{*}{ Languages spoken } & $\leq 2(81)$ & 7.46 & 0.36 & 6.99 & $<0.001^{* * *}$ & 2.26 & 0.51 \\
\hline & $>2(19)$ & 8.10 & & 5.72 & & 2.07 & \\
\hline \multirow[t]{2}{*}{ Education } & Non-literate (51) & 7.78 & 0.47 & 6.03 & 0.23 & 2.09 & $0.043^{*}$ \\
\hline & Literate (49) & 7.38 & & 6.63 & & 1.78 & \\
\hline \multirow[t]{2}{*}{ Food availability } & $<6$ months $(72)$ & 7.51 & 0.65 & 6.36 & 0.84 & 2.04 & 0.75 \\
\hline & $>6$ months (28) & 7.78 & & 6.25 & & 2.14 & \\
\hline
\end{tabular}

***Highly significant, **Moderately significant, *Low significant, $>0.05$ Non-significant (Ns)

All species except B. ciliata were used for livelihood and ritual uses. $P$. cerasoides emerged as important for participants for ritual uses. Other ritual species with less IASc $(<0.5)$ reported in this study were Ficus religiosa $L$., Mangifera indica L., Butea monosperma (Lam.) Kuntze, and Selinum wallichianum (DC.) Raizada \& H.O. Saxena. All these species have been previously reported as ritual and culturally valuable in $\mathrm{KSL}$, India $[40,115]$. Aegle marmelos (L.) Correa, F. religiosa, P. cerasoides, $M$. indica, and P. emblica L. are cultural and religious plants of Nepal [117]. Participants considered these five trees as Panch pallav (a ritual assortment of five holy leaves) and used them ritually during three major events of life: birth, marriage, and funeral ceremonies. Besides these, Artemisia indica Willd. (Kurjo), Ocimum tenuiflorum L. (Tulsi), and Syzygium cumini (L.) Skeels (Jamun) were also reported as ritual plants in this study.

Other high IASc species such as A. pindrow, C. aciculatus, and Q. lanata from Baitadi District were regarded as useful for livelihood as wood, fuel, and fodder. Since we considered the Baitadi District as relatively more accessible than Darchula, all the useful plants with high consensus of the district are associated with the accessibility and availability. Of the five high IASc $(>0.5)$ species, F. religiosa, P. cerasoides, and Q. lanata are abundant at nearby settlements. The high consensus value species were not only being frequently used in the study area, they were also reported as highly useful in other villages of study districts $[29,99,101,118]$. Of the total eight species with high IASc $(>0.5)$, four were for medicinal purposes and four were for non-medicinal (livelihood and ritual) purposes. This result illustrates that despite living in the same cultural landscape, the species were differently valued, perhaps because of different ethnic groups, accessibility, use values, and livelihood strategies. This result was supported by the fact that none of the highest IASc common species was emerged in quadrat A. Darchula District is relatively undisturbed and more distant than Baitadi District. Traditional healers often cite the distant and undisturbed sites as refuges for both high quality and quantity of medicinal plants and products. Other studies report similar findings from adjoining areas of India [98] and other parts of the world [119, 120], where a higher number of indigenous species with medicinal usage are being used at remote and higher altitudes.

The result of IASc was supported by informant consensus factor FiC. Naturally, both assess the consensus; however, the first assesses the consensus at species level whereas the latter evaluates at use types/category. The highest FiC (0.87) was reported for sociocultural livelihood use (wood, fuel, fodder) followed by 0.85 for cultural/ritual uses in Baitadi District. In contrast, the highest $\mathrm{FiC}$ value $(0.83)$ was recorded for medicinal use in the treatment of gallstone and endocrine aliments in Darchula district. Higher FiC values indicate the consent of informants on the specific use of a plant in a traditional use system [121]. The average $\mathrm{FiC}$ value of Baitadi and Darchula districts showed that ritual use of plants possesses the highest $\mathrm{FiC}$ value $(0.81)$ followed by digestive system disorder (0.76) and infections (0.74). Higher consensus on ritual uses was consistent with the sacredness of the area. Baitadi and Darchula districts are 
the southern parts of the KSL, and they are well known for culture- and religious-based taboos, religious fencing, and a high number of sacred peaks $[57,58,73,80]$.

The frequent use of medicinal plants to cure ailments could be attributed to the high preponderance of digestive and infectious disorders in the area. This account aligns with the government report $[70,122]$ stating the prevalence of diarrhea and dysentery in far-western Nepal. The health and development index, partly a measure of nutritional status, ranks the study districts (Baitadi and Darchula) 66 and 62 among 75 districts of the country [70]. Health was further jeopardized by food deficiencies [39, 47, 89]. The situation was provoked by people drinking contaminated water, eating improperly stored and spoiled foods, and conditions of poor nutrition. The highest number of taxa and use reports for treatment of stomach disorders in Darchula District was also observed by Aryal et al. [29]. Since our study area is a food deficit [123] and 72\% participants had food deficiency $>6$ months year ${ }^{-1}$, the tradition of wild plant collection, use, and management was a common strategy to combat poverty paired with geo-ecological constraints and sacredness of the landscape, resulting in insignificant difference between the groups of people with food deficiencies. The role of plant collection in Darchula and Baitadi districts in complementing food availability was appreciated [29]. The low consensus of plant use between Baitadi and Darchula districts could be due to both cultural divergence, varied accessibility, and physiographic heterogeneity.

We found a cultural distinction in collection, use, and conservation of plants. Mountainous pastoral communities of Darchula people often collect plants from remote areas for medical ethnobotany. They reported that their household economy was complemented by $8.13 \pm 4.75 \%$ from the sales of medicinal plants of rural undisturbed areas whereas less $(5.96 \pm 5.46 \%)$ was reported in Baitadi District. The sedentary hilly farmers of Baitadi District value plants more for social, ritual, and livelihood, and often generalist collectors from nearby areas of settlement forage there. Conversely, the forage from distant forest areas in Darchula was associated with quality products, traditional medicine, and elder healers. Since the Darchula people are occupational traders of medicinal plants, they have long been foraging medicinal plant products from remote and relatively undisturbed areas and selling them to lowland groups and to India and China for food grains. While collecting medicinal plants, many collectors worship and pray to plants and acknowledge the spiritual powers for quality products [91] because they believe that plants become more medicinal when processed both spiritually and materially $[65,66]$. Thus, mountains are valued as sacred sites and destinations for livestock grazing and the collection of quality medicinal plants for rural household [124, 125].

People often trade medicinal plant products such as Allium wallichii Kunth (Ban lasun), A. hypsistum (Jimbu), B. ciliata (Vedaite), Delphinium denudatum Wall. ex Hook.f. (Nirmasi), P. polyphylla (Satuwa), Nardostachys grandiflora DC. (Jatamansi), N. scrophulariflora (Katuko), O. sinensis (Yartsagumbu), Zanthoxylum armatum DC. (Timur), etc. The pursuit of collection, bartering, and trade of medicinal plants was dated back to the 1960s $[8,10,126]$. The plants were bartered for grains in the districts before trading [69], and the tradition was balanced until the 1970s [27, 73, 84]. When the district forest offices were set up in the 1970s, the institutionalized trading practice was started, and abundant species such as B. ciliata, S. chirayita, and Valeriana jatamansii Jones were collected for trading. Nepal Government records (2000-2016) show that S. chirayita was traded 3.6 tons in 1999, 4 tons in 2008, and 2.7 tons in 2016 from both districts [127]. Other local medicinal plants Asparagus racemosus Willd., Berberis asiatica Roxb. ex. DC., and Cinnamomum tamala (Buch.-Ham) Nees \& Eberm. were also collected from both districts in 1999 for marketing purpose [127]. The households involved in collection of $O$. sinensis from remote alpine pasture in Darchula District gathered $140 \mathrm{~kg}$ in 1998 to $1440 \mathrm{~kg}$ in 2004 [128], $4500 \mathrm{~kg}$ in 2008 [129], and $5000 \mathrm{~kg}$ in 2016 [126] indicating the steady growth in collection of high value medicinal plants and products in an effort to earn quick economic returns. Although an in-depth investigation of trade dynamics in the districts was outside of the scope of this study, it is noteworthy that several informants recalled the bartering, citing the importance of traditional trade and lamenting the declining medicinal plant species because of fluctuating and market-driven collection.

Such directed and culture mediated collection and use of plants for personal gain (health and income) over communal incentives (social and ritual significance) yield a direct impact on resource conservation. Persistence of intercultural divergences occurred in specialized medicinal and ritual uses of plants or trade of certain species. The distinction of knowledge of cultural groups substantiates the hypothesis that cultural differences play an important role in the transfer and maintenance of indigenous knowledge. Despite the persistence of different strategies for collecting and utilizing plants, the geographic adversities have strengthened a homogenous strategy of employing locally available plants for livelihood and culture. The way of life in rural hills/mountains involves adjusting to the difficult environment, food deficits, and limited accessibility, with appropriate strategies [94]. Thus, the tie between people, plants, and places is strong and inseparable in Darchula and Biatadi districts of KSL, Nepal. 


\section{Intracultural analysis}

An intracultural difference of plant use knowledge at the individual level was evident with the cultural heritage. Participants' years of residence in the study area, the size of their livestock herd and land, family size, and the time required to access a health post $(p \leq 0.001)$ were positively associated with the ethnomedicinal knowledge of plant use. The greater length of residence in an area helps in accumulating greater vast knowledge required to use the resources wisely [130]. There were two household lineages in Baitadi District, living there for more than 300 years, that described the usefulness of 16 plants and 20 use reports each, higher than the average record (use reports, 14.34; useful plants, 12.68 person $^{-1}$ ). This supports the tenet of a positive association between longer residence and greater knowledge.

Limited access to health centers compels people to use local resources for their primary health care, inferring the role of geography. N. scrophulariflora, A. archangelica, and P. polyphylla are abundant in remote and wild forests and highly medicinal (IASc $>0.5$ ). O. sinensis that grows well in alpine pastures is folkloric as a tonic and antipyretic in Darchula. This could be one reason that local communities forage the wild and distance sites for quality products regardless of the distance and geo-ecological constraints. While herding, summer grazing, and ascending for the collection of medicinal plants, local people share knowledge of plant identification, collection, uses, and management. Horizontal transmission of knowledge among shepherds and herders while herding and transhumance contributes to a high level of knowledge sharing, thus aiding conservation knowledge. Cultural values often aid the knowledge of plant use and collection in high altitude areas [5]. The transhumance practice generates a deep connection to the environment, enhanced by the fact that during this time, the families have limited choices [131]. In our study area, the indigenous livelihood strategies such as animal husbandry, transhumance with their livestock, and medicinal plant collection were interlinked. Livestock ownership associates positively with ethnobotanical knowledge in mountains [132]. The sizes of livestock herd, land owned, and family member were slightly correlated (household land 0.38, household livestock 0.41 , and land livestock 0.48). Larger families own larger herds $[95,133]$ which is important for the transhumance community [134]. Household size increases brought about an increased utilization of medicinal plants, perhaps due to economic pressure in larger families. The positive correlation between medicinal plant use and age has been noted elsewhere [117, 135]. However, we did not obtain a significant relationship between the participants' age and the knowledge of plant use and accepted the null hypothesis. No difference of plant use knowledge along the age was also reported by McMillen [136].

OUR and UUR were insignificant along age whereas the MUR was slightly significant indicating that the knowledge of medicinal plant use insignificantly decreased as age increases. Our results indicated that plant use knowledge was less varied among the participants because in situ transmission is underway when needed as described by Phillips and Gentry [3] and Paniagua-Zambrana et al. [7]. Age group (40-59, 60-79, $>80$ years) analysis also did not reveal significantly different MUR knowledge ( $p=0.46-0.95)$ among them; however, the age group 40-59 years possessed the higher MUR $8.19 \pm 0.53$ comparable to MUR $7.2 \pm 0.79$ of the $>80$ years age group. A non-existent relation $(p=0.32)$ was already reported from adjoining villages of our study sites [75] and semi-arid and transhumance communities of Patagonia, Argentina $(p=0.34)$ [137]. Earlier studies argue that the age group 65-75 holds a greater knowledge of plant use [138]. Guimbo et al. [139] found that gender and age have strong effects on the local knowledge of useful plants. However, in this study, the role of both factors was insignificant in differentiating the knowledge of plant uses. Neither MUR nor UUR was significantly different in relation to gender. However, the OUR was varied $(p=0.023)$ and was higher $(6.72 \pm 5.2)$ among the male participants. This result was supported by the gendered division of labor where males are often engaged in summer grazing, livestock herding, and extraction of plants from inaccessible sites that would take them to relatively remote and distant sites. Pfeiffer and Butz [140] reported that plant use is differentiated with men and women due to resource access and their social roles. Women are more likely involved in managing local resources that are available nearby [141] and are associated with anthropogenic landscapes [34].

A weak association of age and plant use knowledge could be attributed to the (non-random) selective samples and the unwillingness or inability to share information explicitly by the elderly groups. The secrecy of medicinal plant knowledge is a common practice in different parts of the world [142], and it was common among the traditional healers in our study area. In the Baidhya tradition-a local healing tradition in far-western Nepal $[13,75,91]$-the main knowledge of healing is kept with sanctity and secrecy and is confined to few healers. Healers generally believed that the medicines would lose their efficacy if too many people knew about their use. Elders generally consider Sundays and Wednesdays as good days in collection of medicinal plants while Saturdays, Mondays, and Tuesdays are often avoided due to religious considerations. Thus, the plant knowledge often belongs to the specialty domain of a culture and limited number of individuals and may be secretive for this purpose [106], 
whereas other general knowledge is widely available to other community members and freely shared. Species-use curve showed that the curve attained asymptote in Baitadi District (range of respondents age 40-96 years). However, the curve was not leveled-off in Darchula District (range of respondents age 41-102 years). As sampling effort increases in Darchula, more elders/healers will be encountered, and more species are likely to be recorded. Thus, if we consider elders as sample respondents for ethnobotanical studies, a greater number of samples are required in order to find the saturation point of the community consensus and statistically significant values of knowledge [143].

General knowledge such as OUR was commonly shared among communities through cultural learning ( $p$ $=0.06$ ) whereas the specialty knowledge like use of medicinal plants for ailments (MUR, - 0.028) and unique use reports (UUR, 0.85) were transmitted through closed and vertical sharing with directed and dedicated apprenticeships under the tutelage of senior practitioners, resulting in constrained transfer. There were $75 \%$ (57 out of 77) traditional healers that learned medicinal plant use knowledge from their parents and grandparents (vertical transfer), whereas $25 \%$ healers learned themselves or from peer healers (horizontal transfer). Vertical knowledge transmission is often associated with family members and the sharing of secretive knowledge $[13,55]$. Even though the difference was insignificant, the knowledge of healers (MUR $7.79 \pm 0.34$ ) influenced the use of medicinal plant collection and use, comparable to that of non-healers (MUR $6.91 \pm 0.56$ ). Moreover, the knowledge was effaced by the decline of traditional healers and their limited sharing $[29,75]$. Lower population growth in the districts $(0.70-0.92)$ than the national average (1.44) and higher than national outmigration rates (absentee population of $7.51 \%$ higher than the national average $7.23 \%$ ) [70] produced a decline in the number of healers and those with traditional knowledge. Families from the region have migrated to cities and lowlands, resulting in an accentuated decline in indigenous land use and plant collection and use. There were about 15 traditional healers in each study village in KSL, Nepal in 2014 whereas only 6 in each village were reported in the present study. The number of healers is decreasing fast (about 7\% per annum) in KSL, Nepal [75], resulting in threatened knowledge of plant use.

The participants who are non-literate had also significant UUR $(p=0.043)$. MUR was also influenced by the literacy level of participants (non-literate $7.78 \pm 2.81$, literate $7.38 \pm 3.14$ ). Higher knowledge of MUR among the non-literate participants could be attributed to their direct association with forest and natural resources and frequent and first choice of traditional and home-based medicines for ailments. Thorsen and Pouliot [144] showed that the traditional medicine is the first choice and ultimate hope of recovery of chronic illness among rural elders and non-literate people of Nepal. The prevalence of traditional medicine was attributed by the limited number of health workers (one health worker for every 3300 people in Baitadi and 1900 in Darchula) [121] than the traditional healers (one for every 100 people) in Nepal $[145,146]$ and the belief and long-rooted tradition/history of using quality medicinal plants in rural and remote areas. A similar account of higher traditional knowledge of plant use among non-literate participants was reported by Umair et al. [147] in the Pakistan Himalaya. The participants who speak only one or two dialects were significantly knowledgeable to OUR $(p<0.001)$.

Among three response variables, MUR and OUR were significantly different $(p<0.001)$ between the participants of different livelihood type: semi-nomadic communities from rural mountains of Darchula (MUR 8.69 \pm 3.01 ) and sedentary communities with the suburban setting of Baitadi (MUR 6.75 \pm 2.67 ). Most of the people from Darchula District inhabiting in remote areas are occupational medicinal plant collectors and traders and do summer grazing, travelling during transhumance, and often seek high-value medicinal plants for trading purposes. The underprivileged groups (Byanshi and Dalit) were knowledgeable on MUR $(8.07 \pm 3.2)$ however insignificant $(p=0.27)$. They were less knowledgeable on general use reports $(3.60 \pm 3.14, p<0.001)$ and unique use report $1.60 \pm 1.37, p=0.045)$. The Dalit are disadvantaged groups of the country and have limited access to the natural resources in Darchula District because of the sociocultural and caste system [72, 88, 148, 149]. Their limited access could have limited their plant use. MUR was specific to indigenous underprivileged minority groups and rural agro-pastoral livelihood type because of the subsistence economy and historical connectivity to the medicinal plants [54]. OUR was folkloric to their counterpart with the highest significance level $(p<0.001)$. OUR was significantly different $(p<0.001-0.023)$ for five out of seven categorical variables: access to opportunity, gender, occupation, language spoken, and livelihood type. The higher mean values of OUR 7.38 and 8.92 compared to 3.60 and 2.88 respectively of privileged groups and from sedentary communities of Baitadi District indicated that the communities living with more amenities and better privilege were more knowledgeable about general non-medicinal uses (OUR) such as uses for livelihood and rituals and divergent from Darchula people.

Sedentary communities living in low-elevation environments have accommodated livelihood to an economic system based on agriculture, markets, and jobs. Being close to markets, availability of medical supplements in markets and pursuance of agribusiness livelihood contribute to the reduced dependency on medicinal plant resources and 
contribute less to MUR in Baitadi lowlands. The use of modern medicine, increasing road linkages, decreasing plant resource availability, and agricultural intensification are responsible for the changing medicinal plant use knowledge in Baitadi [35]. The use knowledge of ritual and religious plants is still persistent regardless of the modern facility if cultural supplements are unavailable in the markets. High culturally shared species (IASc) are found nearby settlements and common for general uses whereas the specialty use (such as MUR) species are foraged by trained personnel, guided methods and from the remote undisturbed sites [118]. The difference in plant use knowledge may help in diversifying the livelihood strategies in accordance with the environment [150].

\section{Conclusions}

The extensive usage of plants for socioeconomy, livelihood and rituals indicate that the plants, people, and culture in the Nepal Himalaya are inseparable. We found that the knowledge of plant use seems to follow a pattern according to available useful plants as well as the cultural significance of the landscape. However, the latter prevails. The use knowledge of plants coincided with the richness of species and plant families. Foraging by the agro-pastoral communities from the remote undisturbed areas for quality products and medicines in Darchula District was divergent with the collections from ruderal and nearby areas in Baitadi District by generalist collectors for ritual uses. General knowledge of plant use such as OUR was commonly shared among communities through cultural learning whereas the specialty knowledge like the use of medicinal plants for ailments (MUR) and unique use reports different from peers (UUR) was transmitted through closed and vertical sharing with directed and dedicated apprenticeships under the tutelage of senior practitioners. The regional particularities-geographic (isolation, accessibility, settlement) and cultural (livestock, land, length of residence and livelihood, and rites)-seem relevant in explaining the differences in plant use knowledge in Baitadi and Darchula districts, Nepal. These results contribute to a growing body of literature that expands our understanding of patterns of knowledge of useful plants across culture and geography.

\section{Additional files}

Additional file 1: Species use reports and IASc at district level. (XLSX $31 \mathrm{~kb})$

Additional file 2: Socioeconomic variables and their analyses. (CSV $13 \mathrm{~kb}$ )

\section{Abbreviations}

FiC: Informant consensus factor; GoN: Government of Nepal; IASc: Index of agreement on species consensus; KSL: Kailash Sacred Landscape; MUR: Medicinal use report; OUR: Other use report; UUR: Unique use report

\section{Acknowledgments}

Author RMK is thankful to FAU Dissertation Year Support Grant - 2018 for the fieldwork support. The authors are grateful to all the communities who participated in the field and dedicated their invaluable time. Laxmi Mahat, Shiv Bhatta, Prem Bhat, Hira Dhami, Sanjeev Luintel, Sabina Gewali, Santhosh Thapa, Rameshwor Bhattarai, Durga Kutal, Andrew Manzardo, Chris LeBoa, Yagya Adhikari, Arjun Adhikari, and Sanjay Tiwari are acknowledged for their support in the fieldwork, data analyses, and editing drafts.

\section{Funding}

This study was partially supported by Rufford Small Grant Foundation (Grant 21198-2), UK, and FAU Dissertation Year Support Grant - 2018. The funding body itself has no direct role in the design of the study, collection, or analysis of the data and use of results.

\section{Availability of data and materials}

Additional files contain data. Other data contain the names of all participants and cannot be shared in this form.

\section{Authors' contributions}

RMK, MF, RWB, and MC designed the study. RMK and PS conducted the fieldwork and data collection, KBTM conducted the main statistical analysis, and BR carried out the GIS data analysis. RMK analyzed the data and wrote the manuscript. All authors read, corrected, and approved the manuscript.

Ethics approval and consent to participate

Before conducting the interviews, prior informed consent was obtained from all participants. No further ethics approval was required.

\section{Competing interests}

The authors declare that they have no competing interests.

\section{Publisher's Note}

Springer Nature remains neutral with regard to jurisdictional claims in published maps and institutional affiliations.

\section{Author details}

'Ethnobotanical Society of Nepal, GPO Box 19225, New Road, Kathmandu 44600, Nepal. ${ }^{2}$ Department of Geosciences, Florida Atlantic University, Boca Raton, USA. ${ }^{3}$ Department of Anthropology, Florida Atlantic University, Boca Raton, USA. ${ }^{4}$ lia State University, Tbilisi, Georgia. ${ }^{5}$ Department of Forest and Rangeland Stewardship, Colorado State University, Fort Collins, USA. ${ }^{6}$ Institute of Remote Sensing and Digital Earth, Chinese Academy of Sciences, Haidian, Beijing, China. ${ }^{7}$ Department of Forest, District Forest Office, Baitadi, Farwest Nepal, Nepal.

Received: 29 March 2018 Accepted: 31 May 2018

Published online: 11 June 2018

\section{References}

1. Ladio AH, Lozada M. Patterns of use and knowledge of wild edible plants in distinct ecological environments: a case study of a Mapuche community from north western Patagonia. Biodivers Conserv. 2004;13:1153-73.

2. Thomas E, Vandebroek I, Goetghebeur P, Sanca S, Arrázola S, Van Damme P. The relationship between plant use and plant diversity in the Bolivian Andes, with special reference to medicinal plant use. Hum Ecol. 2008;36(6):861-79.

3. Phillips O, Gentry AH. The useful plants of Tambopata, Peru: II. Additional hypothesis testing in quantitative ethnobotany. Econ Bot. 1993;47:33-43.

4. Aldunate C, Armesto J, Castro V, Villagran C. Estidio ethnobotanio en una communidad precordillerana de Antofagasta: Tocoe. Boletin Museo Historia Natural de Chile. 1981;38:183-223.

5. Weckerle CS, Huber FK, Yongping Y, Weibang S. Plant knowledge of the Shuhi in the Hengduan Mountains, Southwest China. Econ Bot. 2006;60(1):3-23.

6. Fadiman M. In: Africa Ethnoboty in the Americas, Voeks R, Rashford J, editors. Marketing, culture and conservaion values of NTFPs: case study of Afro-Ecuadorian use of Piquigua, Heteropsis ecuadonrensis (Acaceae). New York: Springer; 2013.

7. Paniagua-Zambrana N, Camara-Leret R, Bussmann RW, Macia MJ. The influence of socioeconomic factors on traditional knowledge: a cross scale comparison of palm use in northwestrn South America. Ecol Soc. 2014;19(4) https://www.ecologyandsociety.org/vol19/iss4/art9/ 
8. Manzardo AE. Ecological constraints on trans-Himalayan trade in Nepal. Contributions to Nepalese Studies. 1977;4:63-81.

9. Cameron MM. Biodiversity and medicinal plants in Nepal: involving untouchables in conservation and development. Hum Organ. 1996;55(1):84-92.

10. Bista S, Webb EL. Collection and marketing of non-timber forest products in farwestern hills of Nepal. Environ Conserv. 2006:33(3):244-55.

11. Zomer RJ, Trabucco A, Metzger M, Oli KP. Environmental stratification of Kailash Sacred Landscape and projected climate change impacts on ecosystems and productivity. Kathmandu: ICIMOD; 2013. p. 1-136.

12. Farnsworth NR, Morris RW. Higher plants-the sleeping giant of drug development. Am J Pharm Educ. 1976;148:46-52.

13. Bhattarai NK. Medical ethnobotany in Karnali zone, Nepal. Econ Bot. 1992; 46(3):257-61.

14. Bussmann RW, Sharon D. Traditional medicinal plant use in Northern Peru: tracking two thousand years of healing culture. J Ethnobiol Ethnomed. 2006;2:47. https://doi.org/10.1186/1746-4269-2-47.

15. Negi VS, Pathak R, Sekar KC, Rawal RS, Bhatta ID, Nandi SK, Dhyani PP. Traditional knowledge and biodiversity conservation: a case study from Byans valley in Kailash Sacred Landscape, India. J Environ Plan Manag. 2017; https://doi.org/10.1080/09640568.2017.1371006.

16. Vandebroek I, Van Damme P, Van Puyvelde L, Arrazola S, De Kimpe N. A comparison of traditional healers' medicinal plant knowledge in the Bolivian Andes and Amazon. Soc Sci Med. 2004:59:837-49.

17. Toledo BA, Galetto L, Colantonio S. Ethnobotanical knowledge in rural communities of Cordoba (Argentina): the importance of cultural and biogeographical factors. J Ethnobiol Ethnomed. 2009;5:40. https://doi.org/10. 1186/1746-4269-5-40.

18. Byg A, Salick J, Law W. Medicinal plant knowledge among lay people in five eastern Tibet villages. Hum Ecol. 2010;38(2):177-91.

19. Toledo BA, Colantonio S, Galetto L. Knowledge and use of edible and medicinal plants in two populations from the Chaco Forest, Córdoba Province, Argentina. J Ethnobiol. 2007;27(2):218-32.

20. Cetinkaya G. Challenges for the maintenance of traditional knowledge in the Satoyama and Satoumi ecosystems, Noto Peninsula. Japan Hum Ecol Rev. 2009;16:27-40.

21. Thomas E, Vandebroek I, Van Damme P, Goetghebeur P, Douterlungne D, Sanca S, Arrazola S. The relation between accessibility, diversity and indigenous valuation of vegetation in the Bolivian Andes. J Arid Environ. 2009;73:854-61.

22. Soldati GT, de Medeiros PM, Duque-Brasil R, Coelho FMG, Albuquerque UP. How do people select plants for use? Matching the ecological apparency hypothesis with optimal foraging theory. Environ Dev Sustain. 2016; https://doi.org/10.1007/s10668-016-9844-1.

23. Ellen RF. In: Medin DL, Atran S, editors. Modes of subsistence and ethnobiological knowledge: between extraction and cultivation in Southeast Asiar. Cambridge: Folk Biology MIT Press; 1999. ISBN 0262133490.

24. Maffi L. Linguistic, cultural and biological diversity. Annu Rev Anthropol. 2005;29:599-617.

25. Saslis-Lagaudakis CH, Williamson EM, Savolainen V, Hawkins JA. Crosscultural comparison of three medicinal floras and implications for bioprospecting strategies. J Ethnopharmacol. 2011;135:476-87.

26. Prance GT. An ethnobotanical comparison of four tribes of Amazonian Indians. Acta Amazônica. 1972;2(2):7-27.

27. Hitchcock J. Ecologically related differences between communities in west Central Nepal. New Orleans: Paper presented at the annual meeting of the American Anthropological Association; 1973.

28. Pieroni A, Giusti ME, Quave C. Cross-cultural ethnobiology in the western balkans: medical ethnobotany and ethnozoology among albanians and serbs in the Pešter Plateau, Sandžak, South-Western Serbia. Hum Ecol. 2011; 39:333-49.

29. Aryal KP, Poudel S, Chaudhary RP, Chettri N, Chaudhary P, Ning W, Kotru R Diversity and use of wild and non-cultivated edible plants in the Western Himalaya. J Ethnobiol Ethnopmedicine. 2018;14:10. https://doi.org/10.1186/ s13002-018-0211-1.

30. Labeyrie V, Rono B, Leclerc C. How social organization shapes crop diversity: an ecological anthropology approach among Tharaka farmers of Mount Kenya. Agric Hum Values. 2014;31:97-107.

31. Byg A, Balslev H. Diversity and use of palms in Zahamena, Eastern Madagascar. Biodivers Conserv. 2001;10:951-70.

32. Fadiman M. Cultivated food plants: culture and gendered spaces of colonists and the Chachi in Ecuador. J Lat Am Geogr. 2005;4(1):43-57.
33. Reyes-García V, Huanca T, Vadez V, Leonard W, Wilkie D. Cultural, practical, and economic value of wild plants: a quantitative study in the Bolivian Amazon. Econ Bot. 2006;60(1):62-74.

34. Voeks RA. Are women reservoirs of traditional plant knowledge? Gender, ethnobotany and globalization in northeast Brazil. Singap J Trop Geogr. 2007;28:7-20

35. Atreya K, Pyakurel D, Thagunna KS, Bhatta L, Uprety Y, Chaudhary R, Oli BN, Rimal $S$. Factors contributing to the decline of traditional practices in communities from the Gwallek-Kedar area, Baitadi, Kailash Sacred Landscape, Nepal. Environ Manag. 2018; https:/doi.org/10.1007/s00267-018-1009-6.

36. Muller JG, Boubacar R, Giombo ID. The "how" and "why" of including gender and age in ethnobotanical research and community-based resource management. Ambio. 2015:44:67-78

37. Farooquee NA, Saxena KG. Conservation and utilization of medicial plants in high hills of the central Himalayas. Environ Conserv. 1996;23:75-80.

38. Rudel TK, Bates D, Machinguiashi R. A tropical forest transition? Agricultural change, out-migration, and secondary forests in the Ecuadorian Amazon, Ann Assoc Am Geogr. 2002;92:87-102.

39. Brusle T. Choosing a destination and work: migration strategies of Nepalese workers in Uttarakhand, northern India. Mt Res Dev. 2008;28:240-7.

40. Bhatt VP. Loss of cultural values: a threat to biodiversity in Uttranchal Himalaya. Zoos' Print Journal. 2010;17:802-6.

41. Poertner E, Junginger M, Muller-Boker U. Migration in Farwest Nepal. Critical Asian Studies. 2011;43(1):23-47.

42. Turner NJ, Clifton H. It's so different today: climate change and indigenous life ways in British Columbia, Canada. Glob Environ Chang. 2009;19(2):180-90.

43. Heinrich M, Ankil A, Frei B, Weimann C, Sticher O. Medicinal plants in Mexico, healer's consensus and cultural importance. Soc Sci Med. 1998;47: 1859-71.

44. Lardos A, Heinrich M. Continuity and change in medicinal plant use: the example of monasteries on Cyprus and historical atrosophia texts. J Ethnopharmacol. 2013;150:202-14.

45. Gairola S, Sharma J, Bedi YS. A cross-cultural analysis of Jammu, Kashmir and Ladakh (India) medicinal plant use. J Ethnopharmacol. 2014;155:925-86.

46. Aziz MA, Adnan M, Khan AH, Sufyan M, Khan SN. Cross-cultural analysis of medicinal plants commonly used in ethnoveterinary practices at South Waziristan Agency and Bajaur Agency, Federally Administrated Tribal Areas (FATA), Pakistan. J Ethnopharmacol. 2018;210:443-68.

47. Chaudhary RP, Shrestha KK, Jha PK, Bhatta K. Kailash Sacred Landscape conservation initiative feasability assessment report. Kathmandu: Ecological Society of Nepal; 2010.

48. Pant SD. The social economy of the Himalaya, vol. 264. London: George Allen and Unwin; 1935.

49. Garbyal SS, Aggrawal KK, Babu CR. Traditionally used medicinal plants in Dharchula Himalayas of Pithoragarh. Indian J Tradit Knowl. 2005a;4:199-207.

50. Elliott A. Botanical exploration of Darchula District, Farwest Nepal. Scottish Rock Garden Club, Royal Botanic Garden Edinburgh. Edinburgh: The University of Edinburgh; 2012.

51. Pandey GD. Nityananda Smarak Samiti. Varanasi; 1989. p. 546-7.

52. Manzardo AE, Dahal DR, Rai NK. The Byanshi: an ethnographic note on a trading group in Farwestern Nepal. Contrib Nepalese Stud. 1976; 3:83-118.

53. Pandey A, Kotru R, Pradhan N. Kailash Sacred Landscape: bridging cultural heritage, conservation and development through a transboundary landscape approach. In: Verschuuren B, Futura N, editors. Asian sacred natural sites: philosophy and practice in protected areas and conservation. NY: Routledge; 2016.

54. Shrestha S. The Vedic-Aryan entry into contemporary Nepal-a pre-historical analysis based on the study of Puranas. Ancient Nepal. 2001;147:1-8.

55. Cameron MM. On the edge of the auspicious: gender and caste in Nepal. IL: University of Illinois Press; 1998.

56. Kumar S. Rana polity in Nepal. Origin and growth. Bombay, India: Asia Publishing House; 1967.

57. Oakley ES, Gairola TD. Himalayan Folklore: Kumaon and west Nepal. Bibliotheca Himalayica II(10), 315. Kathmandu: Ratna Pustak Bhandar; 1977.

58. Sharma DR. Vir khamba (commemorative stone pillars for heroic individuals who contributed to the nation) of western Nepal. Contrib Nepalese Stud. 1997;24:57-70.

59. Farooquee NA, Samal PK, Saxena KG. Adaptation, culture and sustainability in a high Himalayan asociety: case of Bhotiyas. Man Life. 1994;20:201-8. 
60. FAO. Land cover map of Himalaya Region. Rome: Global Land Cover Network Food and Agriculture Organization; 2010.

61. Kunwar RM, Mahat L, Sharma LN, Shrestha KP, Kominee H, Bussmann RW. Underutilized plant species in Farwest Nepal. J Mt Sci. 2012;9(5):589-600.

62. Uddin K, Chaudhary S, Chettri N, Kotru R, Murthy M, Chaudhary RP, Ning W, Shrestha SM, Gautam SK. The changing land cover and fragmenting forest on the roof of the world: a case study in Nepal's Kailash Sacred Landscape. Landsc Urban Plan. 2015;141:1-10.

63. Zomer RJ, Oli KP. Kailash sacred landscape conservation initiative: feasibility assessment report. Kathmandu: ICIMOD; 2011. ISBN: 9789291152117

64. IUCN. Nepal iso-potential agro-ecological zone map. Kathmandu, Nepal: IUCN, Nepal, HMG/DANIDA, NARMSAP, TISC; 2000.

65. Chandrashekara UM, Sankar S. Ecology and management of Sacred Groves in Kerala, India. For Ecol Manag. 1998;112:165-77.

66. Garbyal SS, Grover A, Aggrawal KK, Babu CR. Traditional phytomedicinal knowledge of Bhotias of Dharchula in Pithoragarh. Indian J Tradit Knowl. 2007;6:360-4.

67. Joshi BD. Exploration for amaranth in North-West India. Plant Genet Resour Newslett. 1981;48:41-52.

68. Balick MJ, Cox PA. Plants, people and culture: the science of ethnobotany. New York: Scientific American Library; 1996. p. 230

69. Clarke RC. Traditional cannabis cultivation in Darchula District, Nepal—seed, resin and textiles. J Ind Hemp. 2007;12:19-42.

70. GoN. Nepal Population Report 2011 [Internet]. Kathmandu; 2011. Available from: https://unstats.un.org/unsd/demographic/sources/census/wphc/ Nepal/Nepal-Census-2011-Vol1.pdf. Population Report 2011.pdf.

71. GoN. Nepal Human Development Report 2014-beyond geography, unlocking human potential. Kathmandu, Nepal: UNDP, Government of Nepal; 2014. p. 128.

72. Cameron MM. Considering Dalits and political identity in imagining a new Nepal: special issue on Dalits in Nepal. Himalaya. 2009;27(1-2):5-18.

73. Chhetri R, Pandey TR. Use group forestry in Farwestern Region of Nepal: case studies from Baitadi and Accham. Kathmandu, Nepal: International Center for Integrated Mountain Development; 1992.

74. Devkota R, Karmacharya SB. Documentation in indigenous knowledge of medicinal plants in Gwallek VDC, Baitadi, Nepal. Botanica Orientalis. 2003;3: 135-43.

75. Kunwar RM, Acharya RP, Chowdhary CL, Bussmann RW. Medicinal plant dynamics in indigenous medicines in Farwest Nepal. J Ethnopharmacol. 2015;163:210-9.

76. UNFCO. United Nations Field Coordination Office, District Profile: Baitadi. Kathmandu, Nepal: Transition Support Strategy, RCHC Office; 2013.

77. GoN/DOED. Detailed Environmental Management Plan (DEMP) of Pancheswar Multipurpose Project. Kathmandu: Department of Electricity Development, Government of Nepal; 2016. Retrieved from http://www. doed.gov.np/DEMP-of-PMP.php

78. Rasul G, Choudhary DM, Pandit BH, Kollmair M. Poverty and livelihood impacts of a medicinal and aromatic plants project in India and Nepal: an assessment. Mt Res Dev. 2012;32:137-48.

79. Acharya R, Bhattarai B, Dahal N, Kunwar R, Karki G, Bhattarai H. Governance in community forestry in Nepal through forest certification. Int For Rev. 2015;17:1-9.

80. DB B. Community approaches to natural resources management: sacred and non-sacred landscapes in Nepal. Master thesis. Oxford, Ohio: Miami University; 2003.

81. Wickramasinghe A. Anthropogenic factors and forest management in Sri Lanka. Appl Geogr. 1997;17:87-110.

82. Khumbongmayum AD, Khan ML, Tripathi RS. Ethnomedicinal plants in the sacred grooves of Manipur. Indian J Tradit Knowl. 2005;4:21-32.

83. Ramakrishnan PS. Conserving the sacred: from species to landscapes. Nat Resour. 1996;32:11-9.

84. Chand PB, Wilson A. A case study of the development of local forest management in Darchula. Banko Janakari. 1987;1(4):20-3.

85. Nawa K. Ethnic categories and their usages in Byans, Farwestern Nepal. EBHR. 2002;18:36-57.

86. Atkinson ET. The Himalayan Gazzeter. Vol III, part I. Delhi, India: Cosmo publication; 1989. p. 400

87. ANSAB. Market assessments of non-timber forest products in Darchula and Baitadi districts. Kathmandu, Nepal: Asia Network for Sustainable Agriculture and Bioresouces; 2003.

88. Manzardo AE, Dahal DR, Rai NK. Land and migration in Farwestern Nepal. Kathmandu: INAS press; 1977.
89. UNWFP. United Nations World Food Programme. Food Secur Bull. 2006; 38(5):1-8.

90. Edwards DM. Non-timber forest products from Nepal: aspects of the trade in medicinal and aromatic plants FORESC monograph no. 1/96. Kathmandu: Ministry of Forest and Soil Conservation; 1996.

91. Cameron MM. Trading health: biodiversity conservation, traditional medicine, natures, and the poor in South Asia. Anthropology CourseReader. Detroit: Gale; 2011.

92. Heim A, Gansser A. The throne of the gods. York, New York: The McMillan Co; 1939.

93. von Haimendorf C. Himalayan traders; life in highland Nepal. London: John Murray; 1975.

94. Macfarlane A. Resources and population: a study of the Gurungs of Nepal. Cambridge: Cambridge university press; 1976. p. 364.

95. Rawat G, Rawal RS, Chaudhary RP, Pieli S. Strategies for the management of high altitude rangalans and their interfaces in the Kailash Sacred Landscape. Kathmandu: ICIMOD; 2013. p. 30.

96. Mehra BS, Mathur PK. Livestock grazing in the great Himalayan National Park Conservation Area—a landscape level assessment. Himalaya. 2001; 21(2):14. http://digitalcommons.macalester.edu/himalaya/vol21/iss2/14

97. Jianlin $\mathrm{H}$, Richard $\mathrm{C}$, Hanotte $\mathrm{O}, \mathrm{McV}$ eigh $\mathrm{C}$, JEO R. Yak production in central Asian highlands. Proceedings of the third international congress on yak held in Lhasa, P.R. China, 4-9 September 2000. Nairobi, Kenya: ILRI (International Livestock Research Institute). p. 2002, 572.

98. Garbyal SS, Aggrawal KK, Babu CR. Return of biodiversity in Dharma valley, Dharchula Himalayas, northern India following fortuitous changes in traditional lifestyle of the local inhabitants. Curr Sci. 2005b;88:722-5.

99. Kunwar RM, Baral K, Paudel P, Ahcarya R, Thapa K, Cameron M, Bussmann RW. Landuse and socioeconomic change, medicinal plant selection and biodiversity resilience in Farwestern Nepal. PLoS One. 2016;11(12):e0167812.

100. Mutchnick PA, McCarthy BC. An ethnobotanical analysis of the tree species common to the subtropical moist forest of the Peten, Guatemala. Econ Bot. 1997:51:158-83.

101. Kunwar RM, Mahat L, Acharya RP, Bussmann RW. Medicinal plants, traditional medicine, markets and management in farwest Nepal. J Ethnobiol Ethnomed. 2013;9(2) http://www.ethnobiomed.com/content/9/1/24

102. Putnam AM. The tea shop as an arena of ethnic interaction in Nepal. Contrib Nepalese Stud. 1975;2:11-7.

103. Albuquerque UP, Lucena P. Methods etechicas para coleta de dados. In: Albuquerque UP, Lucena P, editors. Methods e technicas na Pesquisa ethnobotanica. NUPEAEA/Livro Rapido, Recife; 2004. p. 37-62.

104. Kristensen M, Baslev H. Perceptions, use and availability of woody plants among the Gourounsi in Burkina Faso. Biodivers Conserv. 2003;12:1715-39.

105. FEM C. Economic botany data collection standard. Kew, UK: Royal Botanic Gardens; 1995. p. 146.

106. Trotter R, Logan M. Informant consensus: a new approach for identifying potentially effective medicinal plants. In: Etkin NL, editor. Plants in indigernous medicine and diet: biobehavioral approaches. Bedford Hills, NY: Redgraves publishers; 1986. p. 91-112.

107. Vandebroek I. The dual intercultural and intracultural relationship between medicinal plant knowledge and consensus. Econ Bot. 2010;64(4):303-17.

108. Weckerle CS, de Boer H, Puri RK, van Andel T, Bussmann RW, Leonti M. Recommended standards for conducting and reporting ethnopharmacological field studies. J Ethnopharmacol. 2018;210:125-32

109. Heinrich M, Edwards S, Moerman DE, Leonti M. Ethnopharmacological field studies: a critical assessment of their conceptual basis and methods. J Ethnopharmacol. 2009;124:1-17.

110. Sokal RR, Rholf FG. Biometry. New York: Freeman and Company; 1995.

111. Searle SR, Speed FM, Milliken GA. Population marginal means in the linear model: an alternative to least squares means. Am Stat. 1980;34(4):216-21.

112. Case RJ, Pauli GF, Soejarto DD. Factors in maintaining indigenous knowledge among ethnic communities of Manus Island. Econ Bot. 2005; 59(4):356-65.

113. Moerman DE. Symbols and selectivity: a statistical analysis of Native American medical ethnobotany. J Ethnopharmacol. 1979;1:111-9.

114. Pandey TR, Bhatta GD, Kandel DR, Basnet R. Collection and digitization of Herbarium specimens from Kailash Sacred Landscape-Nepal. Plant Resour. 2017;15:4-13.

115. Shah NC, Joshi MC. An ethnobotanical study of the Kumaon region of India. Econ Bot. 1971;25:414-22. 
116. Gangwar KK, Deepali, Gangwar RS. Ethnomedicinal plant diversity in Kumaun Himslaya of Uttarakhand, India. Nat Sci. 2010;8:66-78.

117. Majupuria T, Joshi D. Religious and useful plants of Nepal \& India: medicinal plants and flowers as mentioned in religious myths and legends of Hinduism and Buddhism. India: Rohit Kumar publishers; 2009. p. 312.

118. Pant SR, Dhami NR, Panta IR. Wild edible plants of Lekham area, Darchula, Farwestern Nepal. Scientific World. 2005;3:73-7.

119. Byg A, Vormisto J, Balslev H. Influence of biodiversity and road access on palm extraction at landscape scale in SE Ecuador. Biodivers Conserv. 2007; 16:631-42. https://doi.org/10.1007/s10531-005-1342-y

120. Adnan M, Holscher D. Diversity and abundance of medicinal plants among different forest-use types of the Pakistani Himalaya. Econ Bot. 2011;66:344-56

121. Teklehaymanot T, Giday M. Ethnobotanical study of medicinal plants used by people in Zegie Peninsula, northwestern Ethiopia. J Ethnobiol Ethnomed. 2007;3:12.

122. DDO. District Development Office profile. Nepal: Darchula and Baitadi; 2010.

123. Bradford P. Food security indices for Nepal. Kathmandu: International Center for Integrated Mountain Development; 2018. http://geoapps.icimod.org/ npfoodsecurity?utm_content=buffer7d3ee\&utm medium=social\&utm source=facebook.com\&utm_campaign=buffer

124. Christensen M, Bhattarai S, Devkota S, Larsen HO. Collection and use of wild edible fungi in Nepal. Econ Bot. 2008;62(1):12-23.

125. Pouliot M, Pyakurel D, Smith-Hall C. High altitude organic gold: the production network for Ophiocordyceps sinensis from farwestern Nepal. J Ethnopharmacol. 2018; https://doi.org/10.1016/j.jep.2018.02.028

126. DFO. District Forest Office profile. Baitadi, Nepal; 2016.

127. GoN. Our forests series (Hamro Ban in Nepali) (2006-2016). Kathmandu: Department of Forests, Government of Nepal; 2016.

128. Chhetri R, Lodhiyal LS. Collection of Ophiocordyceps sinensis and its implication to rural livelihood and biodiversity conservation: a case of Darchula, Nepal. In: Jha PK, Karmacharya SB, Chettri MK, Thapa CB, Shrestha $B B$, editors. Medicinal plants in Nepal: an anthology of contemporary research, ecological society. Nepal; 2008. p. 214-23.

129. Pal TB. A study on Ophiocordyceps sinensis (Yartsagumba) collection in Darchula District of Nepal. Kathmandu: Central Department of Economics, Tribhuvan University, (MSC thesis); 2009.

130. Wilkinson DY. Traditional medicine in America families: reliance on wisdom of elders. Marriage Fam Rev. 1987;11:65-76.

131. Ladio AH, Lozada M. Comparison of wild edible plant diversity and foraging strategies in two aboriginal communities of northwestern Patagonia. Biodivers Conserv. 2003;12:937-51.

132. Chinsembu KC, Neumbo J, Likando M, Mbangu A. An ethnobotanical study of medicinal plants used to treat livestock diseases in Onayena and Katima Mulilo, Namibia. S Afr J Bot. 2014:94:101-7.

133. Mafimisebi TE, Oguntade AE, Fajemisin AN, Aiyelari OP. Local knowledge and socio-economic determinants of traditional medicines' utilization in livestock health management in Southwest Nigeria. J Ethnobiol Ethnomed. 2012:8:2. https://doi.org/10.1186/1746-4269-8-2

134. Aryal S, Maraseni TN, Cockfield G. Sustainability of transhumance grazing systems under socio-economic threats in Langtang, Nepal. J Mt Sci. 2014; 11(4):1023-34

135. Finerman R, Sackett R. Using home gardens to decipher health and healing in the Andes. Med Anthropol Q. 2003;17(4):459-82.

136. McMillen $\mathrm{H}$. Ethnobotanical knowledge transmission and evolution: the case of medicinal markets in Tanga. Tanzania Econom Botany. 2012;66(2):121-31.

137. Lozada M, Ladio A, Weigandt M. Cultural transmission of ethnobotanical knowledge in a rural community of northwestern Patagonia, Argentina. Econ Bot. 2006;60(4):374-85.

138. Mahwasane ST, Boadua LMN. An ethnobotanical survey of indigenous knowledge on medicinal plants used by the traditional healers of the Lwamondo, Limpopo province, South Africa. S Afr J Bot. 2013;88:69-75.

139. Guimbo D, Muller IJ, Larwanou M. Ethnobotanical knowledge of men, women and children in rural Niger: a mixed methods approach. Ethnobotany Res Appl. 2011;9:235-42.

140. Pfeiffer J, Butz R. Assessing cultural and ecological variation in ethnobotanical research: the importance of gender. J Ethnobiol. 2005;25:240-87.

141. Momsen J. Gender and Devlopment. London: Routeledge; 2004.

142. Kala CP. Indigenous uses, population density, and conservation of threatened medicinal plants in protected areas of the Indian Himalayas. Conserv Biol. 2005;19:368-78.
143. Heck KL, Van-Belle G, Simberloff D. Explicit calculation of the rarefaction diversity measurement and the determination of sufficient sample size. Ecology. 1975;56(6):1459-61.

144. Thorsen RS, Pouliot M. Traditional medicine for the rich and knowledgeable: challenging assumptions about treatment-seeking behavior in rural and peri-urban Nepal. Health Policy Plan. 2016;31:314-24.

145. Gillam S. The traditional healer as village health worker. J Inst Med. 1989;11: $67-76$.

146. WRI. The wealth of the poor: managing ecosystems to fight poverty. USA: World Resource Institute; 2005. http://www.wri.org/publication/worldresources-2005-wealth-poor-managing-ecosystems-fight-poverty

147. Umair M, Altaf M, Abbasi LM. An ethnobotanical survey of indigenous medicinal plants in Hafizabad district, Punjab-Pakistan. PLoS One. 2017;12(6): e0177912. https://doi.org/10.1371/journal.pone.0177912.

148. Graner E. Kami (blacksmiths) today: forests and livelihood security. Contrib Nepalese Stud. 1997;24(2):217-31

149. Folmar S, Cameron M, Pariyar M. Digging for Dalit: social justice and an inclusive anthropology of Nepal. Hot Spots, Cultural Anthropology website, October. 2015;14 https://culanth.org/fieldsights/739-digging-for-dalit-socialjustice-and-an-inclusive-anthropology-of-nepal

150. Quave $\mathrm{CL}$, Pieroni A. A reservoir of ethnobotanical knowledge informs resilient food security and health strategies in the Balkans. Nat Plants. 2015:14021.

\section{Ready to submit your research? Choose BMC and benefit from:}

- fast, convenient online submission

- thorough peer review by experienced researchers in your field

- rapid publication on acceptance

- support for research data, including large and complex data types

- gold Open Access which fosters wider collaboration and increased citations

- maximum visibility for your research: over $100 \mathrm{M}$ website views per year

At BMC, research is always in progress.

Learn more biomedcentral.com/submissions 